\title{
Environmental Sensitivity in New Zealand Dairy Cattle
}

\author{
J. R. Bryant, ${ }^{\star 1}$ N. López-Villalobos, ${ }^{*}$ J. E. Pryce, † C. W. Holmes, ${ }^{\star}$ D. L. Johnson, $†$ and D. J. Garrick* ${ }^{\star} \ddagger$ \\ *Institute of Veterinary, Animal and Biomedical Sciences, Massey University, Private Bag 11-222, Palmerston North, New Zealand \\ †Livestock Improvement Corporation, Private Bag 3016, Hamilton, New Zealand \\ ‡Department of Animal Sciences, Colorado State University, Fort Collins 80523
}

\begin{abstract}
This study quantifies the extent of within-breed sire reranking for milk production traits in a range of environments encountered within New Zealand. Character states of herds were formed within the environmental ranges of herd fat plus protein (MS) yield, summer heat load index (HLI), herd size, and altitude. Single-trait and bivariate sire models across breeds were then applied for estimation of genetic parameters and genetic correlations between extreme character states. A low degree of sire reranking occurred, as measured by genetic correlations around 0.9 , between herd environments that differed widely in MS yield (227 vs. $376 \mathrm{~kg}$ of MS per cow), and HLI (61.4 vs. 69.6). The HLI of 61.4 and 69.6 are approximately equivalent to average summer maximum temperatures of 19 and $25^{\circ} \mathrm{C}$ at $80 \%$ humidity. Correlations of sire estimated breeding values in extreme character states were low, but only one was below an expected correlation accounting for the reliability of prediction. The results show the environment in New Zealand is not sufficiently diverse to warrant separate breeding schemes for different environments.
\end{abstract}

Key words: genotype by environment interaction, multibreed, clustering

\section{INTRODUCTION}

Numerous recent studies have reported genetic variation in environmental sensitivity of dairy cattle sires, as measured by phenotypic responses of their progeny to different nutritional and climatic environments (Ravagnolo and Misztal, 2000; Kadzere et al., 2002; Kolver et al., 2002; Hayes et al., 2003; Linnane et al., 2004). Generally, genetic variation in environmental sensitivity results in an increase in phenotypic differences in milk production between sires associated with increased average performance; that is, a scaling effect (Hill et al., 1983; Visscher and Hill, 1992). However, in

Received April 6, 2006.

Accepted November 6, 2006

${ }^{1}$ Corresponding author: Jeremy.Bryant@agresearch.co.nz some cases in which large variations in environment exist, sires may rerank (Zwald et al., 2003a; Kearney et al., 2004).

Global sales of semen expose progeny of sires to climates and production systems vastly different from their original selection environment. This may cause sire reranking because the progeny of some sires are not expected to perform to their optimum in every different environment (Mulder et al., 2006). This fact has been recognized by Canadian producers who use intensive grazing because they are concerned that their current evaluation system may not rank bulls adequately for their specific needs (Boettcher et al., 2003). The United States also estimated sire genetic merit on a regional and national basis until 1995 because of the expectation that genotype $\times$ region interactions may be important (Norman et al., 2005). In New Zealand, similar questions exist for those producers who use significant amounts of feeds other than grazed pasture, because these producers often prefer to use sires proven in intensive production environments such as the United States or Canada.

Environmental clusters, or character states, of herds are often formed to reflect similar climatic and production levels, with performance in each character state being treated as genetically distinct traits (de Jong and Bijma, 2002; Fikse et al., 2003a; Zwald et al., 2003a; Ceron-Munoz et al., 2004). The estimated genetic correlations between environmental character states can then be tested to determine whether they depart significantly from 1 (unity). Commonly, the estimated genetic correlations between different environments range between 0.9 and unity, indicating minimal reranking of sires among or within countries (Weigel et al., 1999; Calus and Veerkamp, 2003; Zwald et al., 2003a; Kolmodin et al., 2004). Genetic correlations close to unity are generally observed when comparing average and high production environments, expected to use medium to high levels of concentrate feeds (Veerkamp and Goddard, 1998; Cromie, 1999; Kolmodin et al., 2002; Calus and Veerkamp, 2003; Rekaya et al., 2003). Significant reranking of sires has been observed, however, in studies by Kolmodin et al. (2002), Hayes et al. (2003), and Zwald et al. (2003a) with wide variations 
in environment within and between countries expected to arise from different levels of concentrate feed usage. For example, Hayes et al. (2003) observed genetic correlations of 0.70 to 0.83 for yields of milk, fat, or protein when comparing the 5th and 95th percentile of herds in Australia that achieved average test-day protein yields of 0.54 and $1.10 \mathrm{~kg} / \mathrm{cow}$ per day.

Environmental factors that cause reranking have been related to nutrition, climate, and herd size. Nutritional (or production) environment, in the absence of information on levels and types of feeds offered to the herd, is generally classified on the basis of herd averages or standard deviations for total or peak yields of milk, fat, or protein (Calus and Veerkamp, 2003; Fikse et al., 2003b; Zwald et al., 2003a). Climatic environment of the herd can be described using regional measures of rainfall or temperature (Fikse et al., 2003a; Zwald et al., 2003a), or localized measures such as a temperature-humidity index (Ravagnolo et al., 2000; Hayes et al., 2003). Herd size may be based on contemporary group size, number of first-lactation animals, or actual size of the herd.

Production environment, herd size, and climate differ greatly among New Zealand herds. Average yields of milk are 3,913 kg per cow, much lower than yields in other countries (International Committee for Animal Recording, 2005). Nevertheless, fat plus protein (MS) yields per cow exhibit significant regional differences (Livestock Improvement Corporation, 2004). In Northland, the far north of the North Island, average MS yield is $246 \mathrm{~kg}$ (2,947 kg of milk) compared with Southland, the far south of the South Island, where average MS yield is $362 \mathrm{~kg}(4,251 \mathrm{~kg}$ of milk; Livestock Improvement Corp., 2004). Average herd size is 302 cows but approximately 31 and $13 \%$ of herds have a herd size of less than 200 or greater than 500 cows, respectively (Livestock Improvement Corp., 2004). Mean daily maximum air temperature is $5.0^{\circ} \mathrm{C}$ higher in the north of the North Island than in the south of the South Island (National Institute of Weather and Atmospheric Research, 2005). Therefore, to determine if sires can be used with confidence throughout New Zealand in any environment, it is important to determine if variations in herd size, production environment, and climate cause reranking of sires.

Genetic evaluation of New Zealand dairy cattle is undertaken using an animal model, adjusting for scaling effects associated with superior environments, analyzing all breeds and breed crosses simultaneously. Breeding value estimates are on one scale, allowing direct comparison of individual animals regardless of breed (Harris et al., 1996). To ensure correct withinbreed selection of the best sires for each environment, it is important to determine if sire by environment in- teractions are more than a scaling effect, and if they extend to rerank sires between environments. The objective of this study was to determine if within-breed sire reranking for milk yield traits occurred within New Zealand between different production, heat stress, herd size, or altitudinal environments.

\section{MATERIALS AND METHODS}

\section{Production Data}

Initial data comprised 711,096 records of total lactation yields and yield deviations for milk, fat, and protein from animals of various ages in sire-proving scheme herds of the Livestock Improvement Corporation. These herds progeny tested all of the young sires from 1989 to 2003. Herd-year-season (HYS) groups were formed, with season corresponding to calving in either autumn or spring. Records that were $<50 \mathrm{~kg}$ of protein, $<100$ DIM, or from HYS groups with less than 5 animals were discarded.

Total lactation yields were calculated from test-day records and intervals between tests, with the total lactation comprising the period from $\mathrm{d} 5$ after parturition until $15 \mathrm{~d}$ after the last test. Total 270-d lactation yield deviations for milk, fat, and protein were calculated from test-day yields, with each test-day record weighted according to the number of tests, stage of lactation at test, and intervals between tests (Johnson, 1996).

A pedigree file was obtained for all animals in the analysis, traced back to the 1940s whenever possible. The breed composition of overseas Holstein-Friesian (OHF), imported or derived from primarily North America bloodlines (Harris and Kolver, 2001), New Zealand Friesian (NZF), New Zealand Jersey (NZJ), and other breeds that included Ayrshire, Guernsey, and Milking Shorthorn were calculated. Heterosis and recombination coefficients were calculated for each of the breed crosses $(\mathrm{OHF} \times \mathrm{NZF}, \mathrm{OHF} \times \mathrm{NZJ}, \mathrm{NZF} \times \mathrm{NZJ}$, and grouped OHF/NZF/NZJ $\times$ other) using the method described by VanRaden and Sanders (2003) and Wolf et al. (1995). Genetic groups for phantom parents were formed based on year of birth and breed (general OHF/ NZF, NZJ, or other). A genetic group within breed was assigned for all animals born between 1940 and 1970, but thereafter, genetic groups were formed in 10-yr blocks. Some small genetic groups, such as 1980-1989 and 1990 onward, when animal recording was common, were merged within breeds.

\section{Formation of Environmental Character States}

Four environmental factors were considered: 1) adjusted HYS total MS yield, a proxy for feed consumption levels; 2) summer heat load index (HLI), a measure 
of the degree of prolonged heat stress; 3) herd size, a reflection of stress imposed by competition; and 4) altitude. These environmental factors were chosen due to a high likelihood for interaction between genotype and environment (Ravagnolo and Misztal, 2000; Fikse et al., 2003a; Kolmodin, 2003), or because they have not been studied in a New Zealand context (i.e., altitude). They are easily calculated and generally known by commercial producers.

Adjusted total lactation MS yield using total lactation data, as opposed to total 270-d lactation yield deviations, for each HYS was obtained using the GLM procedure of SAS (version 8, SAS Institute, Cary, NC). The model included fixed effects of HYS, age (years at calving), breed (OHF/NZF, crossbred, NZJ, and other), and lactation length fitted as a covariate. Lactation length was included because there is significant variation in lactation length due to heavy reliance on grazed pasture. Adjusting for breed effects ensured that all character states contained a range of cow breeds. For example, $\mathrm{OHF}$ and NZF achieve higher MS yields than NZJ at comparative levels of intakes. Therefore, if an adjustment for breed was not included, the high MS yield character state may have contained herds with mainly OHF and NZF cattle. Similarly, the very low MS yield character state may have contained only herds with mainly NZJ cattle.

Summer HLI for each HYS was calculated from meteorological data for 1989 to 2002, obtained from 65 stations by the National Institute of Water and Atmospheric Research. Meteorological station data included map reference, daily measures of maximum and minimum temperature, rainfall, average relative humidity, solar radiation, and wind speed. These data were then used to calculate summer HLI (Castaneda et al., 2004) for each year:

$$
\begin{gathered}
\mathrm{HLI}=34.1+(0.26 \times \mathrm{RH})+(1.33 \times \mathrm{BGT}) \\
-\left(0.82 \times \mathrm{WS}^{0.1}\right)-\mathrm{Log}^{0.4 \times\left(0.0001+\mathrm{WS}^{2}\right)}
\end{gathered}
$$

where $\mathrm{RH}$ is mean daily relative humidity divided by 100 , BGT is black globe temperature $\left({ }^{\circ} \mathrm{C}\right)$, calculated as:

$$
(1.33 \times \mathrm{T})-(2.65 \times \sqrt{\mathrm{T}})+[3.21 \times \log (\mathrm{SR}+1)+3.5,
$$

where $\mathrm{T}$ is air temperature $\left({ }^{\circ} \mathrm{C}\right)$ at $1200 \mathrm{~h}, \mathrm{SR}$ is solar radiation $\left(\mathrm{MJ} / \mathrm{m}^{2}\right)$, and WS is mean daily wind speed $(\mathrm{m} / \mathrm{s})$.

The Livestock Improvement Corporation supplied map coordinates for each herd. Herds and meteorological stations were spatially located on a map (Figure 1) using Arc View GIS (Version 3.2, ESRI, Redlands, CA). The nearest meteorological station with complete cli-

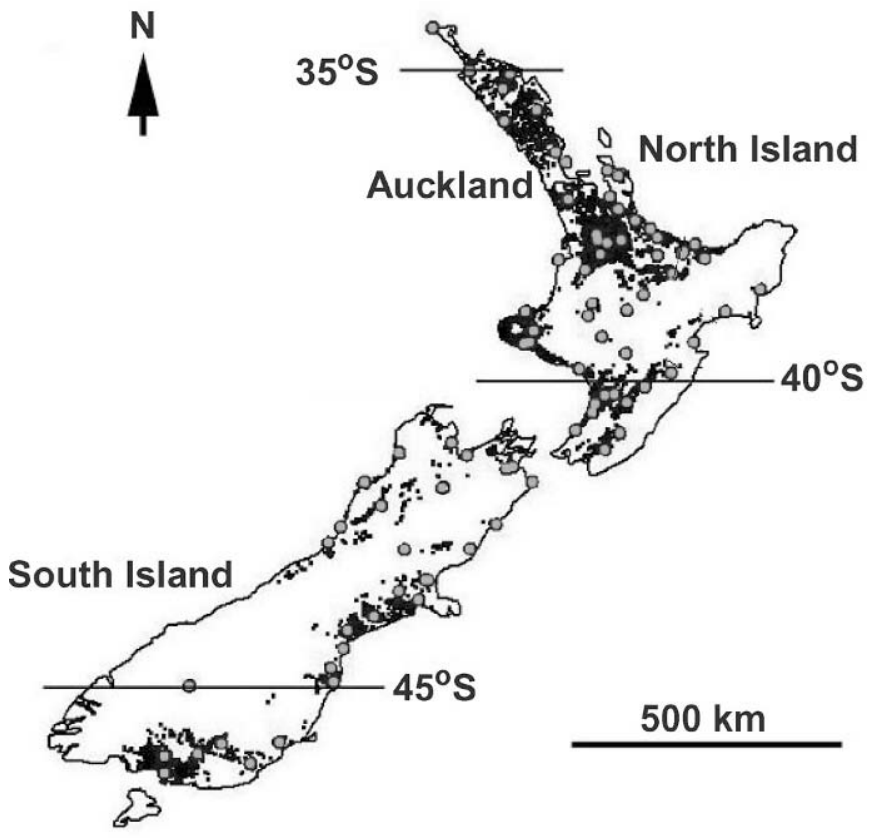

Figure 1. Spatial location of dairy farms (small black dots) and meteorological stations (medium grey filled circles).

mate data (within a $50-\mathrm{km}$ radius), was found using the Nearest Neighbor Script 3.4 (Weigel, 2004), and was used to determine summer HLI for that particular HYS. Some $30 \%$ of cow records were lost because farms did not have HLI data within a $50-\mathrm{km}$ radius.

Herd size was based on yearly estimates of the number of lactating animals in each herd that was provided by the sire-proving scheme participants at the start of a season. Herd size data were only available for years in which a herd participated in the sire-proving scheme, resulting in only $39.7 \%$ of data being available for analysis. Farm altitude was estimated in Arc View GIS by aligning a map with the spatial location of farms and a digital elevation map where altitude was estimated every $100 \mathrm{~m}$.

Character states of HYS were formed for each environmental parameter using the FASTCLUS procedure of SAS (Version 8; SAS Institute Inc., Cary, NC), based on the k-means algorithm. At least 40,000 records were needed to ensure that a reasonable number of sires had a sufficient number of daughters $(>20)$ in each environmental character state for meaningful genetic correlation estimates. Four character states were considered for MS yield and HLI, and 3 character states for herd size and altitude. Only 3 character states were considered for altitude because a large proportion of herds were at low altitudes. 


\section{Estimation of Genetic Parameters}

The univariate multibreed sire model, in matrix notation, applied to all first-lactation (2-yr-old) records $(184,288)$ across all or within each environmental character state was

$$
\mathbf{y}=\mathbf{X b}+\mathbf{Z} \mathbf{s}+\mathbf{e},
$$

where $\mathbf{y}$ is the vector of 2-yr-old records for milk, fat, or protein total yield deviations; $\mathbf{b}$ is the vector of fixed effects of HYS, second-order polynomial regressions on age at parturition (in months), linear regressions on parturition date deviation from the mean HYS parturition date, breed proportions (NZF, OHF, NZJ, and other), heterosis, and recombination coefficients; $\mathbf{s}$ is the vector of random additive genetic effects of sire; $\mathbf{X}$ and $\mathbf{Z}$ are incidence matrices associating records with the elements of $\mathbf{b}$ and $\mathbf{s}$, respectively; and $\mathbf{e}$ is the vector of random residuals.

Residual effects were assumed to have mean zero and be independently normally distributed with variance $\left(\sigma_{\mathrm{e}}^{2}\right)$. Accordingly, $\mathrm{E}[\mathrm{y}]=\mathrm{Xb}, \operatorname{var}\left(\mathbf{s}_{\mathbf{i}}\right)=\mathbf{A} \sigma_{\mathrm{s}}^{2}$, and $\operatorname{var}(\mathbf{e})=$ $\mathbf{I} \sigma_{\mathrm{e}}^{2}$, where $\mathbf{A}$ is the numerator relationship matrix for sires and ancestral sires, $\sigma_{\mathrm{s}_{\mathrm{i}}}^{2}$ is the sire variance, and $\mathbf{I}$ is an identity matrix. Variance components and solutions for random effects were calculated in each character state environment using an average information restricted maximum likelihood algorithm (Johnson and Thompson, 1995). Only first-lactation records were used because this facilitated a simpler analysis through the removal from the statistical model of a permanent effect of cow. In addition, inclusion of multiple-aged cows would have required an adjustment for heterogeneity of variance between different age groups. Random sire solutions $(\hat{\mathbf{s}})$ were transformed to EBV using $\hat{\mathbf{u}}+$ $\mathbf{Q} \hat{\mathbf{b}}+\mathbf{2} \hat{\mathbf{s}}$, where $\mathbf{Q}$ is a matrix relating fractions of breed group effects to the sire, $\hat{\mathbf{b}}$ is a vector of fixed additive breed group effects or breed group means, and $\hat{\mathbf{s}}$ is a vector of random additive transmitting effects for sires (Arnold et al., 1992).

\section{Tests for Reranking Between the Top and Bottom Character States for Each Environmental Descriptor}

Genetic Correlations. Genetic correlations were estimated by applying a bivariate version of the univariate model to lactation yield deviations in which performance in each character state was treated as a distinct trait. Animals were included in the analysis if 1 ) their sire had at least 2 daughters in each of the 2 corresponding environments, and 2) there were a minimum of 4 animals in their HYS group.
Observed vs. Expected Correlations Between Sire $\boldsymbol{E B V}$. Testing the significance of genetic correlation estimates is not straightforward, because the distribution of the estimates is not known. Therefore, as an alternative to genetic correlation estimates, observed correlations $\left(\mathbf{r}_{\mathbf{o}}\right)$ between EBV of commonly used sires (reliability in excess of 0.40 or approximately $>15$ daughters in each character state) from the extreme character states for each environmental parameter were calculated. The $r_{0}$ value was obtained by pooling within-breed variances and covariances for each major sire breed. The $r_{0}$ value was then compared with the simulated expected distribution of the correlation $\left(\mathbf{r}_{\mathbf{e}}\right)$ that was calculated using the procedure described by Garrick (2005), assuming the null hypothesis of a genetic correlation between environments equal to 1 . The simulation of the expected distribution of correlations requires knowledge of the reliability of the EBV from each character state. Sire reliabilities in each character state were estimated as

$$
1-\left(\frac{S E P^{2}}{\sigma_{\mathrm{s}}^{2}}\right)
$$

where $S E P^{2}$ is the squared standard error of prediction derived from the inverse of the coefficient matrix and the average information restricted maximum likelihood estimate of the sire variance is assumed to be the true parameter. A value where $r_{0}$ is lower than the 0.05 percentile of $r_{e}$ indicates that the true genetic correlation between character states is significantly less than unity.

Environment-Specific Selection Differential. The economic impact of selecting sires nationally as compared with selecting sires within character states was quantified by computing selection differentials for the top 20 sires. The selection criterion was an economic index (EI) of lactation value calculated as: $\left(E B V_{\text {Fat }} \times\right.$ $\left(E V_{\mathrm{Fat}}\right)+\left(E B V_{\text {Pro }} \times\left(E V_{\text {Pro }}\right)+\left(E B V_{\text {Milk }} \times\left(E V_{\text {Milk }}\right)\right.\right.$, where $E B V_{\text {Fat }}, E B V_{\text {Pro }}, E B V_{\text {Milk }}$ are EBV for fat, protein, and milk, respectively, and $E V_{\text {Fat }}, E V_{\text {Pro }}, E V_{\text {Milk }}$ are New Zealand dairy industry 2006 economic values reported at $1.251 / \mathrm{kg}$ of fat, $6.328 / \mathrm{kg}$ of protein, and $-0.07 / \mathrm{L}$ of milk (Animal Evaluation, 2006). The top 20 national sires were first identified from an analysis that included data from all character states. Within each separate analysis for a particular character state, EI were recalculated using the environment state-specific EBV. The average EI for the best 20 sires in that state, selected after calculating the EI of all sires in a character state, was then compared with the average EI for the best 20 sires nationally. The resulting difference in average merit would be zero if the best 20 sires nationally were also the best in that particular state; otherwise, the 
Table 1. Character state means (standard deviation) of environmental descriptors and corresponding numbers of herd-year-seasons (HYS), animals, sires, average breed proportions, and percentage of total 2-yr-old data for each character state

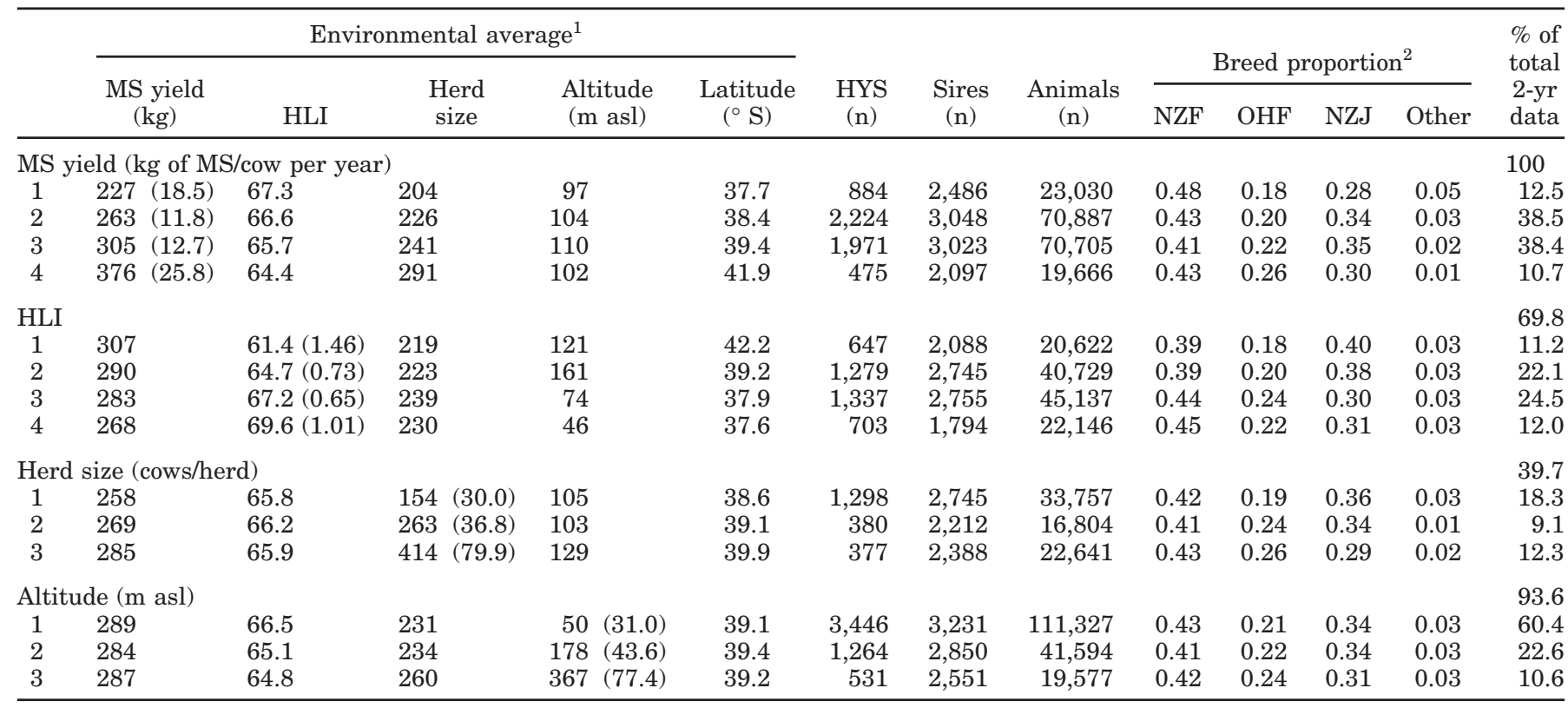

${ }^{1} \mathrm{MS}$ yield = fat plus protein yield; HLI = heat load index; asl = above sea level.

${ }^{2}$ Breeds: NZF $=$ New Zealand Friesian; OHF = overseas Holstein-Friesian; NZJ = New Zealand Jersey.

selection differential would be positive. Denoting the average EI of the best 20 environment state-specific sires in character state $k$ as $\bar{X}_{E I}^{E S S_{s}}$ sires and the EI of the best 20 sires nationally in character state $k$ as $\bar{X}_{E I_{k}}^{S S} S_{i r e s}$, the environment state-specific selection differential is

$$
\bar{X}_{E I_{k}}^{E S S_{\text {sires }}}-\bar{X}_{E I_{k}^{S}}^{S S_{\text {ires }}}
$$

\section{RESULTS}

The majority of sire proving scheme dairy herds were located in Northland (midpoint of lat 35.5, long 174.2) or Waikato (lat 37.5, long 175.2; Figure 1). Other regions that were heavily represented were Taranaki (lat 39.2, long 174.2), Manawatu (lat 40.2, long 175.2), Canterbury (lat 43.5, long 171.2), and Southland (lat 46.1, long 168.2). Each farm generally had at least 1 weather station within a $50-\mathrm{km}$ radius; however, not all had sufficient measurements to estimate HLI.

Average character state yields for MS ranged from 227 to $376 \mathrm{~kg}$ of MS/cow (Table 1). The 2 extreme MS yield states were the smallest, incorporating $884(12.5 \%$ of total data) and 475 HYS (10.7\% of total data), respectively (Table 1). High MS yield herds tended to be located at more southern latitudes (Table 1). For example, for every $1^{\circ}$ change in latitude in a southern direction, MS yield increased by $6.45 \mathrm{~kg}$ after fitting a simple linear regression $\left(R^{2}=0.16\right)$. All data were available for MS yield as the measure of environment. Average character state HLI ranged from 61.4 to 69.6 (Table 1). The HLI of 61.4 and 69.6 represented the extreme character states in this study and are approximately equivalent to average summer maximum temperatures of 20 and $25^{\circ} \mathrm{C}$ or temperature-humidity indices of 68 and 74, respectively. Lower HLI herds tended to be located at southern latitudes (Table 1). For example, for every $1^{\circ}$ change in latitude in a southern direction, HLI decreased by 0.73 after fitting a simple linear regression $\left(\mathrm{R}^{2}=0.40\right)$. The least number of HYS were represented in the coldest (61.4 HLI) character state.

Average character state herd size ranged from 154 to 414 lactating animals per herd (Table 1). Larger herds achieved significantly higher MS yields. Herd size ranged from 70 to 830 cows per herd. Average character state farm altitude ranged from 50 to $367 \mathrm{~m}$ above sea level. Heat load index was reduced at high altitudes, and farm altitude did not affect MS yields. Most $(60.4 \%)$ herds were located at altitudes of less than $100 \mathrm{~m}$ above sea level (Table 1).

Heritability estimates were, on average, highest for milk, followed by protein and fat yields (Table 2). Sire variance increased with MS yield (Figure 2), as did residual variance but at a lesser rate such that heritability increased with MS yield (Table 2). For the remaining environmental parameters, differences in character state environment had little effect on heritability estimates. 
Table 2. Estimates of heritability (on the diagonal) and genetic correlations (below the diagonal) between character states for each environmental descriptor for milk, fat, and protein yields

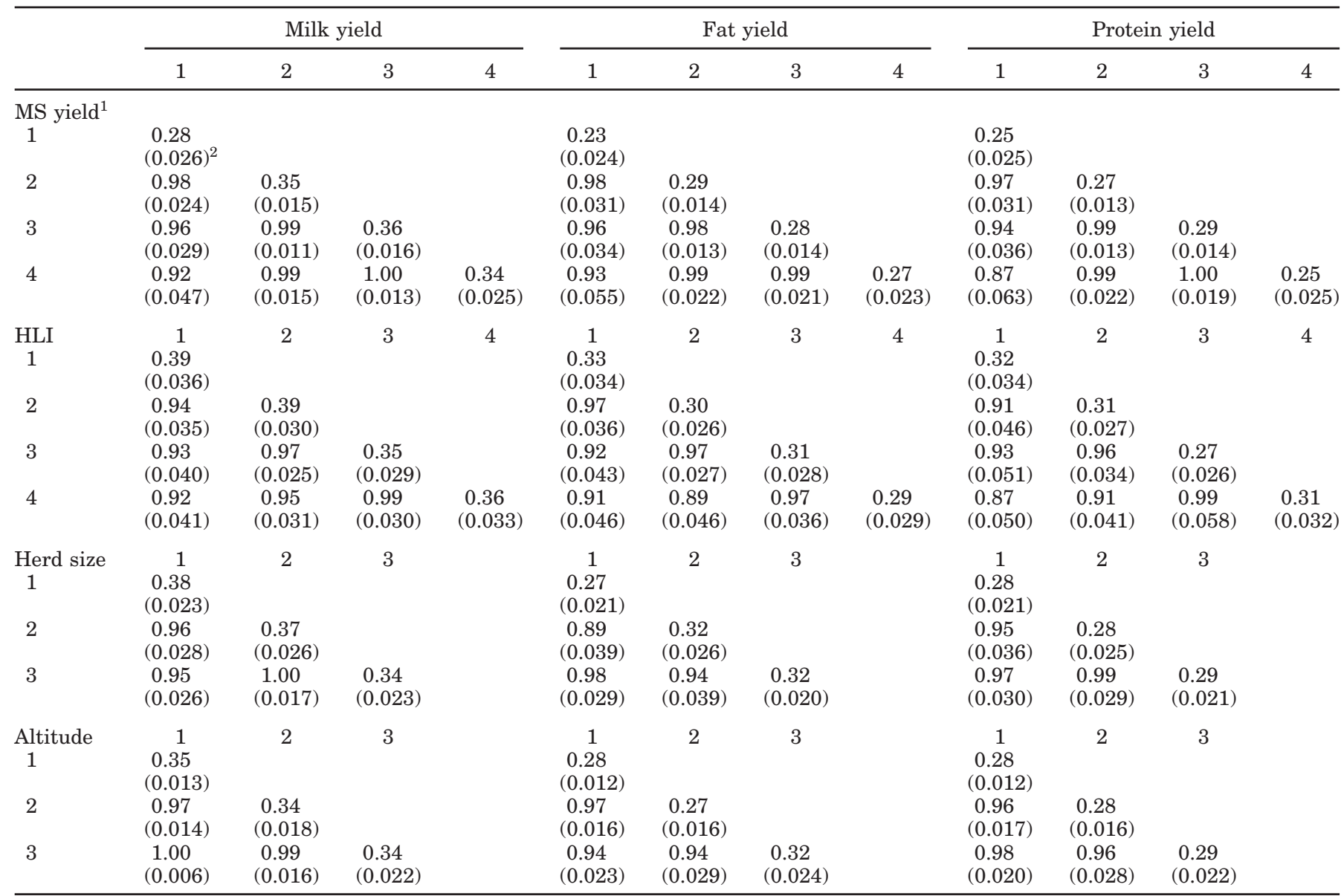

${ }^{1} \mathrm{MS}$ yield = fat plus protein yield; HLI = heat load index.

${ }^{2}$ Standard error values in parentheses.

Genetic correlation estimates were generally in excess of 0.9 , with only a few comparisons below 0.9 (Table 2). Nevertheless, the genetic correlations between extreme character states tended to be lower for MS and HLI than for herd size or altitude. Only for fat yield when comparing low and high altitudes herds were observed correlations below expected values computed at the 0.05 probability level (Table 3 ).

Environment-specific selection differentials were greatest in the MS yield environment that averaged $376 \mathrm{~kg}$ of MS per cow and was NZ $\$ 10.5$ (Table 4). This is about equivalent to the value of one year's genetic trend. Environment-specific selection differentials averaging greater than NZ\$5 were observed in the environments that achieved low MS yields, experienced low HLI, comprised large herds, and were located at high altitudes. Negligible advantages were observed by selecting sires based solely on daughter performance in low-altitude herds. Selection on EI within character state resulted in higher average sire EBV for milk, fat, and protein yield in environment state-specific selection sires $\left(\mathbf{E S S}_{\text {sires }}\right)$ over standard selection sires $\left(\mathbf{S S}_{\text {sires}}\right.$; Table 4).

\section{DISCUSSION}

There was little evidence of major sire reranking for milk, fat, or protein yield within New Zealand. Genetic correlations were above 0.80 (Table 2), a threshold level suggested by Robertson (1959), and well in excess of 0.60 suggested by Mulder et al. (2006) as a break-even point that warrants separate breeding schemes for environments of equal importance. Genetic correlation estimates between nutrition or production environment, as measured by herd MS yield, are similar to the range of 0.74 to 0.98 within a country presented by Konig et al. (2005) when summarizing international studies. The correlation estimates between sire EBV obtained in this 
Table 3. Observed $\left(r_{0}\right)$ and expected $\left(r_{e}\right)$ correlations (at the 0.05 probability level) between EBV for milk, fat, and protein yields for the bottom and top character states for environmental descriptors ${ }^{1}$

\begin{tabular}{|c|c|c|c|c|c|c|}
\hline & \multicolumn{2}{|c|}{ Milk } & \multicolumn{2}{|c|}{ Fat } & \multicolumn{2}{|c|}{ Protein } \\
\hline & $r_{o}$ & $r_{e}$ & $r_{o}$ & $r_{e}$ & $r_{0}$ & $\mathrm{r}_{\mathrm{e}}$ \\
\hline MS yield & 0.63 & 0.53 & 0.51 & 0.43 & 0.44 & 0.43 \\
\hline HLI & 0.65 & 0.53 & 0.51 & 0.47 & 0.50 & 0.50 \\
\hline Herd size & 0.71 & 0.59 & 0.60 & 0.52 & 0.56 & 0.51 \\
\hline Altitude & 0.85 & 0.67 & $0.64 *$ & 0.65 & 0.69 & 0.63 \\
\hline
\end{tabular}

${ }^{1} \mathrm{MS}$ yield $=$ fat plus protein yield $; \mathrm{HLI}=$ heat load index. $*$ Observed correlation is significantly different to the 0.05 percentile of expected correlations.

study (Table 3) fluctuated around the rank correlation values reported by Cromie (1999), Calus et al. (2002), Kolmodin et al. (2002), and Kearney et al. (2004).

Selection differentials indicated that small benefits of environment-specific selection would occur in an environment that achieves low MS yields (Table 4). The $\mathrm{EI}$ and corresponding yield traits of some of the $\mathrm{SS}_{\text {sires }}$ dropped based solely on the performance of their daughters in low MS yield environments. Out of the 20 sires selected on EI in a general genetic evaluation, 11 and 13 were still in the top 20 sires when selecting based on performance in low and high MS yield herds, respectively. By contrast, 17 out of the 20 sires selected on $\mathrm{EI}$ in a general genetic evaluation were still in the top 20 sires based on performance in herds located at low altitudes. There was also some benefit in the environment-specific selection of sires in herds, which experienced low HLI, were large, or were located at high altitudes. Further investigation is needed to determine the level at which environmental-specific differentials become economically important, warranting the publi- cation of environment-specific EBV or environmental sensitivity information. Different sires may be selected in different environments if environment-specific breeding schemes were set up. However, the small gain in genetic progress for fat and protein yield would likely not offset the cost of an undesirable increase in milk yield (which has a negative economic weighting), or the costs associated with setting up an environmentspecific selection scheme.

A potential reason for some sire reranking may be a reduced consumption ability or genetic-drive of one genotype compared with another genotype when each is subjected to a specific environment (Bryant et al., 2005). For example, Kyriazakis et al. (1999), Yearsley et al. (2001), and Illius et al. (2002) proposed that animals adapt or evolve to the environment in which they were selected. The evolutionary adaptations that allow specific genotypes to function better in one environment include the ability to dissipate heat easily (Bianca, 1965) and consume and process concentrates faster than other genotypes. At the genomic level, genes responsible for production traits may show different expression (degree of penetrance) in different environments (Lin and Togashi, 2002). For example, those genes may be switched on or off depending on the environmental conditions in which the animal is managed (de Jong, 1990; Via et al., 1995). Evidence of such a switching mechanism was provided by Rutherford and Lindquist (1998), who found that a deformed eye trait in Drosophila was expressed more frequently at high temperatures. Possibly, environmental-switch mechanisms also occur in dairy cattle.

On average, MS yields were greater at lower latitudes (Table 1). This may have been due to supplementation
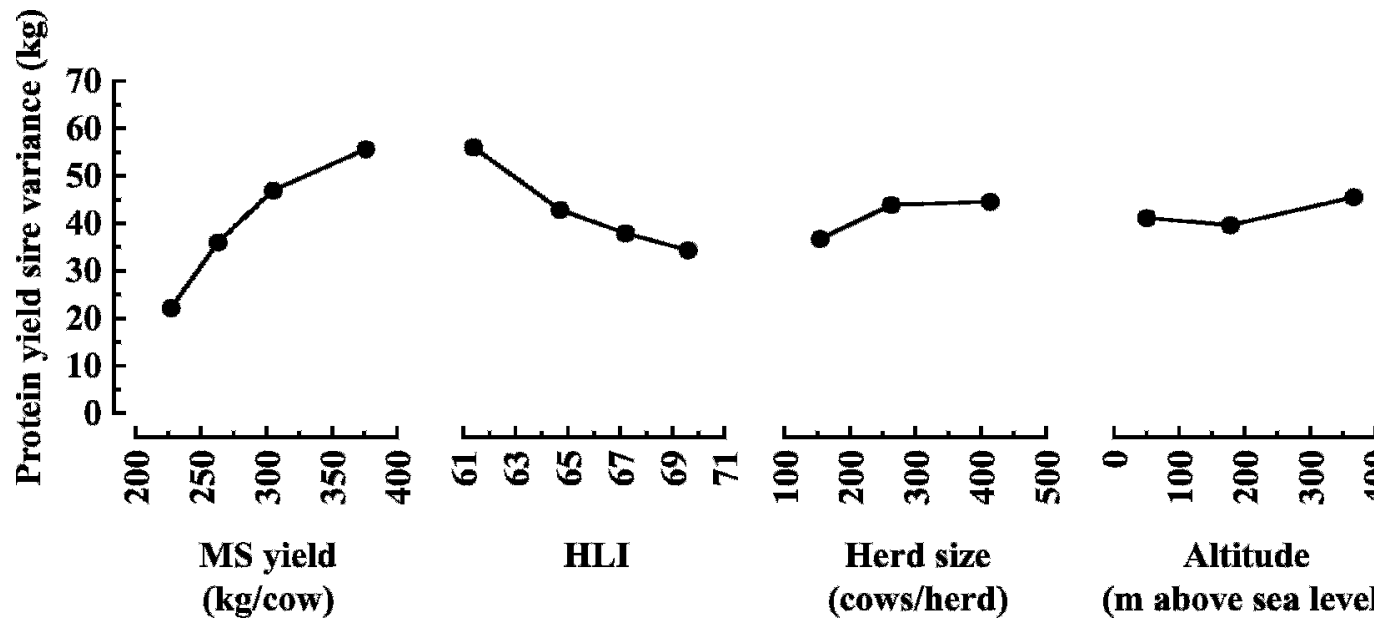

(kg/cow)

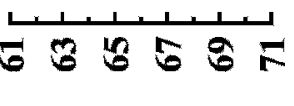

HLI Herd size
(cows/herd)

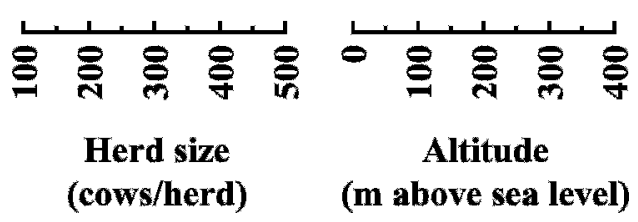

Figure 2. Sire variances $(-)$ for protein yield for each environmental character state parameter. MS yield = fat plus protein yield; HLI = heat load index. 
Table 4. Environment-specific selection differentials ${ }^{1}$ for milk, fat, and protein yield and economic index (EI) in the lowest and highest character state for each environmental descriptor

\begin{tabular}{|c|c|c|c|c|c|c|c|c|c|}
\hline \multirow[b]{2}{*}{ Environment $^{2}$} & \multicolumn{2}{|c|}{ Milk (kg) } & \multicolumn{2}{|c|}{ Fat (kg) } & \multicolumn{2}{|c|}{ Protein (kg) } & \multicolumn{3}{|c|}{$\mathrm{EI}(\$ N Z)$} \\
\hline & $\mathrm{ESS}_{\text {sires }}$ & $\mathrm{SS}_{\text {sires }}$ & $\mathrm{ESS}_{\text {sires }}$ & $\mathrm{SS}_{\text {sires }}$ & ESS $_{\text {sires }}$ & $\mathrm{SS}_{\text {sires }}$ & $\mathrm{ESS}_{\text {sires }}$ & $\mathrm{SS}_{\text {sires }}$ & Advantage \\
\hline \multicolumn{10}{|l|}{ MS yield (kg) } \\
\hline 227 & 316 & 270 & 7.5 & 6.1 & 10.1 & 8.2 & 50.9 & 40.4 & +10.5 \\
\hline 376 & 495 & 408 & 7.5 & 5.7 & 12.9 & 10.9 & 56.1 & 47.4 & +8.7 \\
\hline \multicolumn{10}{|l|}{ HLI } \\
\hline 61.4 & 394 & 349 & 9.0 & 6.4 & 13.5 & 12.0 & 68.9 & 59.3 & +9.6 \\
\hline 69.6 & 405 & 368 & 9.5 & 8.8 & 11.3 & 10.0 & 55.2 & 48.5 & +6.7 \\
\hline \multicolumn{10}{|c|}{ Herd size (cows/herd) } \\
\hline 154 & 485 & 456 & 9.7 & 8.6 & 13.6 & 13.0 & 64.1 & 61.0 & +3.1 \\
\hline 414 & 378 & 340 & 3.4 & 1.3 & 10.0 & 8.7 & 41.3 & 32.9 & +8.3 \\
\hline \multicolumn{10}{|c|}{ Altitude $(\mathrm{m} \text { asl })^{3}$} \\
\hline 50 & 450 & 405 & 9.3 & 9.3 & 13.6 & 12.8 & 66.0 & 64.1 & +1.9 \\
\hline 367 & 544 & 402 & 5.8 & 4.5 & 14.0 & 11.2 & 57.8 & 48.5 & +9.3 \\
\hline
\end{tabular}

${ }^{1} \mathrm{ESS}_{\text {sires }}=$ average $\mathrm{EI}$ of the top 20 sires selected based on performance within an environment; $\mathrm{SS}_{\text {sires }}=$ average EI of the top 20 sires within an environment, which were selected based on performance in a standard general evaluation.

${ }^{2} \mathrm{MS}$ yield $=$ fat plus protein yield; HLI = heat load index.

${ }^{3}$ Meters above sea level.

being greater at lower latitudes (although this cannot be confirmed) or an effect of summer HLI on animal performance and feed availability. The summer HLI encountered in the warmest character state environment would not be normally associated with heat stress conditions (Ravagnolo and Misztal, 2000; Zwald et al., 2003b; Castaneda et al., 2004). However, New Zealand dairy cows walk long distances, and are exposed to wind and very high solar radiation levels, all of which can modify the HLI value when heat stress occurs (Bianca, 1965; Kadzere et al., 2002; McKenzie et al., 2003). Alternatively, greater performance at more southern latitudes may be related to cows being exposed to shorter photoperiods before parturition. Cows exposed to short, compared with long, photoperiods before parturition are reported to have greater mammary development, resulting in increased milk yields in the former cows (Miller et al., 2000; Wall et al., 2005).

There was limited evidence for significant reranking among different herd sizes. In comparison with our study, Zwald et al. (2003b) estimated a genetic correlation of 0.78 when comparing herds with an average of 30 and 2.5 first-lactation animals per year, respectively. Konig et al. (2005) estimated genetic correlations for protein yields of 0.79 and 0.92 when comparing large herds ( $\geq 150$ cows) in the eastern states of Germany with small herds ( $\leq 50$ cows) in western states of Germany and with small and large herds in eastern states, respectively. Fikse et al. (2003a) using data from Guernsey cows in 4 countries (Australia, Canada, United States, and South Africa) observed a genetic correlation of 0.94 between small and large herds. Kondo et al. (1989) showed that, under conditions of excessively large group sizes, individual animals found it difficult to memorize their social rank within the herd and consequently, aggressive interactions increased. Under predominantly grazing conditions, any genotype-based advantage in large or small group sizes might not be expressed to the extent of intensive environments.

In conclusion, this study has provided insight into the environmental heterogeneity experienced by the New Zealand dairy cattle population. The results confirm that there was insufficient sire reranking in New Zealand to warrant formation of separate breeding schemes for different environments.

\section{ACKNOWLEDGMENTS}

The senior author would like to acknowledge the support of an Enterprise Doctoral Scholarship provided jointly by the Livestock Improvement Corporation and the Foundation for Research, Science and Technology.

\section{REFERENCES}

Animal Evaluation. 2006. Report of the AE Economic Data Working Group. www.aeu.org.nz. Accessed March 8, 2006.

Arnold, J. W., J. K. Bertrand, and L. L. Benyshek. 1992. Animal model for genetic evaluation of multibreed data. J. Anim. Sci. 70:3322-3332.

Bianca, W. 1965. Reviews of the progress of dairy science. Section A. Physiology. Cattle in a hot environment. J. Dairy Res. 32:291-345.

Boettcher, P. J., J. Fatehi, and M. M. Schutz. 2003. Genotype $\times$ environment interactions in conventional versus pasture-based dairies in Canada. J. Dairy Sci. 86:383-404.

Bryant, J. R., N. López-Villalobos, C. W. Holmes, and J. E. Pryce. 2005. Simulation modelling of dairy cattle performance based on knowledge of genotype, environment and genotype by environment interactions. Curr. Status Agric. Syst. 86:121-143. 
Calus, M. P. L., A. F. Groen, and G. de Jong. 2002. Genotype $\times$ environment interaction for protein yield in Dutch dairy cattle as quantified by different models. J. Dairy Sci. 85:3115-3123.

Calus, M. P. L., and R. F. Veerkamp. 2003. Estimation of environmental sensitivity of genetic merit for milk production traits using a random regression model. J. Dairy Sci. 86:3756-3764.

Castaneda, C. A., J. B. Gaughan, and Y. Sakaguchi. 2004. Relationships between climatic conditions and the behaviour of feedlot cattle. Pages 33-36 in Proc. 25th Biennial Conf. Aust. Soc. Anim. Prod., Melbourne, Australia. CSIRO Publishing, Collingwood, Victoria, Australia.

Ceron-Munoz, M. F., H. Tonhati, C. N. Costa, D. Rojas-Sarmiento, and D. M. Echeverri Echeverri. 2004. Factors that cause genotype by environment interaction and use of a multiple-trait herdcluster model for milk yield of Holstein cattle from Brazil and Colombia. J. Dairy Sci. 87:2687-2692.

Cromie, A. R. 1999. Genotype by environment interaction for milk production traits in Holstein Friesian dairy cattle in Ireland. PhD Thesis Queens University of Belfast, UK.

de Jong, G. 1990. Genotype-by-environment interaction and the covariance between environments: Multilocus genetics. Genetica 81:171-177.

de Jong, G., and P. Bijma. 2002. Selection and phenotypic plasticity in evolutionary biology and animal breeding. Livest. Prod. Sci. 78:195-214.

Fikse, W. F., R. Rekaya, and K. A. Weigel. 2003a. Assessment of environmental descriptors for studying genotype by environment interaction. Livest. Prod. Sci. 82:223-231.

Fikse, W. F., R. Rekaya, and K. A. Weigel. 2003b. Genotype $\times$ environment interaction for milk production in Guernsey cattle. J. Dairy Sci. 86:1821-1827.

Garrick, D. 2005. Calculating the distribution of the correlation between estimated breeding values from different analyses. J. Anim. Sci. 83(Suppl. 1):73. (Abstr.)

Harris, B. L., J. M. Clark, and R. G. Jackson. 1996. Across breed evaluation of dairy cattle. Proc. N.Z. Soc. Anim. Prod. 56:12-15.

Harris, B. L., and E. S. Kolver. 2001. Review of Holsteinization on intensive pastoral dairy farming in New Zealand. J. Dairy Sci. 84(E Suppl.):E56-E61.

Hayes, B. J., M. Carrick, P. Bowman, and M. E. Goddard. 2003. Genotype $\times$ environment interaction for milk production of daughters of Australian dairy sires from test-day records. J. Dairy Sci. 86:3736-3744.

Hill, W. G., M. R. Edwards, M. K. Ahmed, and R. Thompson. 1983. Heritability of milk yield and composition at different levels and variability of production. Anim. Prod. 36:59-68.

International Committee for Animal Recording. 2005. Yearly milk enquiry-Online database. http://www.waap.it/enquiry/ Accessed Dec. 21, 2005.

Illius, A. W., B. J. Tolkamp, and J. Yearsley. 2002. The evolution of the control of food intake. Proc. Nutr. Soc. 61:465-472.

Johnson, D. L. 1996. Estimation of lactation yield from repeated measures of test day yields. Proc. N.Z. Soc. Anim. Prod. 56:16-18.

Johnson, D. L., and R. Thompson. 1995. Restricted maximum likelihood estimation of variance components for univariate animal models using sparse matrix techniques and average information. J. Dairy Sci. 78:449-456.

Kadzere, C. T., M. R. Murphy, N. Silanikove, and E. Maltz. 2002. Heat stress in lactating dairy cows: A review. Livest. Prod. Sci. 77:59-91.

Kearney, J. F., M. M. Schutz, P. J. Boettcher, and K. A. Weigel. 2004. Genotype $\times$ environment interaction for grazing versus confinement. I. Production traits. J. Dairy Sci. 87:501-509.

Kolmodin, R. 2003. Reaction norms for the study of genotype by environment interaction in animal breeding. PhD Thesis Swedish Univ. Agric. Sci., Uppsala.

Kolmodin, R., E. Strandberg, B. Danell, and H. Jorjani. 2004. Reaction norms for protein yield and days open in Swedish red and white dairy cattle in relation to various environmental variables. Acta Agric. Scand. 54:139-151.
Kolmodin, R., E. Strandberg, P. Madsen, J. Jensen, and H. Jorjani. 2002. Genotype by environment interaction in Nordic dairy cattle studied using reaction norms. Acta Agric. Scand. 52:11-24.

Kolver, E. S., J. R. Roche, M. J. De Veth, P. L. Thorne, and A. R. Napper. 2002. Total mixed rations versus pasture diets: Evidence for a genotype $\times$ diet interaction in dairy cow performance. Proc. N.Z. Soc. Anim. Prod. 62:246-251.

Kondo, S., J. Sekine, M. Okubo, and Y. Asahida. 1989. The effect of group size and space allowance on the agonistic and spacing behavior of cattle. Appl. Anim. Behav. Sci. 24:127-135.

Konig, S., G. Dietl, I. Raeder, and H. H. Swalve. 2005. Genetic relationships for dairy performance between large-scale and small-scale farm conditions. J. Dairy Sci. 88:4087-4096.

Kyriazakis, I., B. J. Tolkamp, and G. C. Emmans. 1999. Diet selection and animal state: An integrative framework. Proc. Nutr. Soc. 58:765-771.

Lin, C. Y., and K. Togashi. 2002. Genetic improvement in the presence of genotype by environment interaction. Anim. Sci. J. 73:3-11.

Linnane, M., B. Horan, J. Connolly, P. O'Connor, F. Buckley, and P. Dillon. 2004. The effect of strain of Holstein-Friesian and feeding system on grazing behaviour, herbage intake and productivity in the first lactation. Anim. Sci. 78:169-178.

Livestock Improvement Corporation. 2004. Dairy Statistics 2003/ 2004. Livestock Improvement Corporation, Hamilton, New Zealand.

McKenzie, R., D. Smale, and G. Bodeker. 2003. Ozone profile differences between Europe and New Zealand: Effects on surface UV irradiance and its estimation from satellite sensors. J. Geophys. Res. 108:1-9.

Miller, A. R. E., R. A. Erdman, L. W. Douglass, and G. E. Dahl. 2000 Effects of photoperiodic manipulation during the dry period of dairy cows. J. Dairy Sci. 83:962-967.

Mulder, H. A., R. F. Veerkamp, B. J. Ducro, J. A. M. van Arendonk, and P. Bijma. 2006. Optimization of dairy cattle breeding programs for different environments with genotype by environment interactions. J. Dairy Sci. 89:1740-1752.

National Institute of Weather and Atmospheric Research. 2005. The climate of New Zealand. http://www.niwa.co.nz/edu/resources/ climate/overview/ Accessed March 22, 2005.

Norman, H. D., P. M. VanRaden, R. Powell, J. R. Wright, and W. R. Verboort. 2005. Effectiveness of national and regional sire evaluations in predicting future-daughter milk yield. J. Dairy Sci. 88:812-826.

Ravagnolo, O., and I. Misztal. 2000. Genetic component of heat stress in dairy cattle, parameter estimation. J. Dairy Sci. 83:21262130

Ravagnolo, O., I. Misztal, and G. Hoogenboom. 2000. Genetic component of heat stress in dairy cattle, development of heat index function. J. Dairy Sci. 83:2120-2125.

Rekaya, R., K. A. Weigel, and D. Gianola. 2003. Bayesian estimation of parameters of a structural model for genetic covariances between milk yield in five regions of the United States. J. Dairy Sci. 86:1837-1844.

Robertson, A. 1959. The sampling variance of the genetic correlation coefficient. Biometrics 15:469-485.

Rutherford, S. L., and S. Lindquist. 1998. Hsp90 as a capacitor for morphological evolution. Nature 396:336-342.

VanRaden, P. M., and A. H. Sanders. 2003. Economic merit of crossbred and purebred US dairy cattle. J. Dairy Sci. 86:1036-1044.

Veerkamp, R. F., and M. E. Goddard. 1998. Covariance functions across herd production levels for test day records on milk, fat, and protein yields. J. Dairy Sci. 81:1690-1701.

Via, S., R. Gomulkiewicz, G. De Jong, S. M. Scheiner, C. D. Schlichting, and P. H. Van Tienderen. 1995. Adaptive and phenotypic plasticity: Consensus and controversy. Trends Ecol. Evolut. 10:212-217.

Visscher, P. M., and W. G. Hill. 1992. Heterogeneity of variance and dairy cattle breeding. Anim. Prod. 55:321-329.

Wall, E. H., T. L. Auchtung, G. E. Dahl, S. E. Ellis, and T. B. McFadden. 2005. Exposure to short day photoperiod during the 
dry period enhances mammary growth in dairy cows. J. Dairy Sci. 88:1994-2003.

Weigel, J. 2004. Nearest Neighbor Script 3.4. http://arcscripts.esri. com/details.asp?dbid=11765 Accessed Dec. 12, 2004.

Weigel, K. A., T. Kriegl, and A. L. Pohlman. 1999. Genetic analysis of dairy cattle production traits in a management intensive rotational grazing environment. J. Dairy Sci. 82:191-195.

Wolf, J., O. Distl, J. Hyamek, T. Grosshans, and G. Seeland. 1995. Crossbreeding in farm animals. V. Analysis of crossbreeding plans with secondary crossbred generations. J. Anim. Breed. Genet. 112:81-94.
Yearsley, J., B. J. Tolkamp, and A. W. Illius. 2001. Theoretical developments in the study and prediction of food intake. Proc. Nutr. Soc. 60:145-156.

Zwald, N. R., K. A. Weigel, W. F. Fikse, and R. Rekaya. 2003a. Application of a multiple-trait herd cluster model for genetic evaluation of dairy sires from seventeen countries. J. Dairy Sci. 86:376-382.

Zwald, N. R., K. A. Weigel, W. F. Fikse, and R. Rekaya. 2003b. Identification of factors that cause genotype by environment interaction between herds of Holstein cattle in seventeen countries. J. Dairy Sci. 86:1009-1018. 